\title{
Agromet Advisory Bulletin - A Weather Smart Agriculture Technology option for Adaptation and Mitigation of Changing Climate
}

\author{
P.R. Jaybhaye*, N.H. Deore and P.B. Shinde \\ Department of Agricultural Meteorology, Vasantrao Naik Marathwada Krishi Vidyapeeth, \\ Parbhani-431 402 (MS), India \\ *Corresponding author
}

\section{A B S T R A C T}

\section{Keywords \\ $\mathrm{AAB}, \mathrm{AAB}$ format, AMFU, Agro advice etc.}

\section{Article Info}

Accepted:

24 January 2018

Available Online:

10 February 2018
Agrometeorological Field Unit (AMFU) disseminating agromet advisory bulletin (AAB) are embraced three parts viz., weather condition, crop information and weather based agro advisories. This study enlightens the qualitative and quantitative aspect and gaps between providers and end users of $\mathrm{AAB}$. The AAB issued by 7 AMFU stations was collected for the period 5 years (2007-2011) from IMD, Pune and SAU's of 7 states. The substantial variation in the format of issued $\mathrm{AAB}$ by all the stations was observed and formats are not found easily usable to print media, SMS through multimedia. The minimal number of advices observed based on weather and weather element based. The alert message not incorporated in AAB most of the AMFU's except Parbhani and Sehor. Advice on postharvest technology, processing of agricultural produce, marketing and transport was not observed in AAB. It is suggested that adopt pictographic and colourful format 1 or format 2, for commercialization of $\mathrm{AAB}$ through use of e-AAB, TV, internet, specialized App for widespread and usability, which are most useful weather smart agriculture technological tools that can minimise climatic risks and build a resilient agricultural production.

\section{Introduction}

In describing tensions between maximizing global agricultural productivity, increasing resilience of agricultural systems in the face of climate change and mitigating greenhouse gas (GHG) emissions from agriculture, the term climate-smart agricultural development was first used in 2009. A year later, at the First Global Conference on Agriculture, Food Security and Climate Change at the Hague, the concept of climate-smart agriculture (CSA) was presented and defined as agriculture that "sustainably increases productivity, enhances resilience, reduces/removes greenhouse gas emissions, and enhances achievement of national food security and development goals" (Neufeldt et al., 2013).

Amongst the weather parameters rainfall, wind and cloud cover in kharif season and temperature, heavy wind, unseasonal rainfall and hail storm in Rabi season having greatest deciding parameters of Agricultural production to success or failure the season. Arun Khatri Chhetri and Pramod K. Aggarwal 
(2017) reported that the agricultural production systems in all South Asian countries are well known to be sensitive to long-term climate change and short-term (annual and seasonal) weather variability. Consequently, the production systems in the region need to be adjusted focusing on effective management of current as well as future climatic risks. Recently research in South Asia identified a range of options that can minimise climatic risks and build a resilient agricultural production. Depending on their appropriateness for a particular location, these options include, water, energy, nutrient, carbon, weather and knowledge smart technologies, practices and services.

Weather forecast is becoming more important task for efficient management of farm inputs. The accuracy of forecast for a long period is a great challenge, but the medium range weather forecasts in recent year were improved to a great extent due to modern technology. AAB is the best tool for transferring agro techniques and location specific recommendation of SAU's to the end users. The agricultural productions are generally attributed to the behaviour of weather (space and time). It also provides, mitigation techniques on vulnerable information about crop management practices viz., irrigation schedule, pest and diseases status and control management, livestock production and management, marketing and trade management, new scientific storage and processing information to the farmers (Rathore et al., 2004). Similarly, Rao et al., (2008) and Jaybhaye et al., (2018) reported that the weather based $\mathrm{AAB}$ on medium range weather forecast is used to minimize the risk from weather and weather induced pest and diseases.

The demand of the farming community could not be fully met due to certain drawbacks in the agro advisory system, such as nonavailability of skilful weather forecast in all temporal ranges specific to the site of interest to a farmer. Besides this, non-availability of real time crop data lack of decision support system for interpretation of weather forecast into advisories. In order to address the problem judiciously, proper knowledge on agriculture situation prevalent in the region is essential. This may include type, state and stage of crops, prevailing pest and diseases, soil moisture status, state of animal health and nutrition and agricultural marketing situations. Priority should be given to predominant crops of the region and most prevailing problems keeping in view their relative economic importance. Management practices like what, when and how to sow, when and how much to irrigate; what measures to be adopted for plant or animal protection from stresses caused by pest and diseases, temperature, wind and rainfall etc. animal shelter, nutrition and their health are affected by weather to a large extent, hence must find place in the AAS bulletins. The advisories should also serve early warning functions, alerting producers to the implications of various weather events such as extreme temperatures, heavy rains, floods, and strong winds. This article clearly shows that the AAB is one of the technologies for adaptation and mitigation options in agriculture. While, this article are enlighten particular location specific options includes water, energy, nutrient, weather and knowledge smart technologies in AAB, which act as a weather smart agriculture technology option for adaptation and mitigation of changing climate

\section{Materials and Methods}

Forecast of weather parameters viz., rainfall, maximum and minimum temperatures, relative humidity, wind speed and direction received from NCMRWF, Govt. of India New Delhi through regional Indian Meteorological Department centre on every Tuesday and Friday. The present investigation was 
undertaken during the period 2011-12 at Department of Agricultural Meteorology, Vasantrao Naik Marathwada Krishi Vidyapeeth and Parbhanito study Agromet Advisory Bulletin to mitigate the impact of climate change on agriculture. $\mathrm{AAB}$ were issued by the AMFU's of the last five year. $\mathrm{AAB}$ is published regularly twice in a week viz., Tuesday and Friday generally by all AMFU's. The data on AAB issued was collected from Indian Meteorological Department, Pune and State Agriculture Universities across the nation. Data was collected from seven centres of one season for the period of last five year (2007-2011).

The Agromet Advisory Bulletins from seven AMFU stations were collected from four states which are mainly using either Marathi or Hindi language for the present study. The names of AMFU stations were Parbhani, Rahuri, Akola and Dapoli (Maharashtra state), Sehor (Madhya Pradesh), Jaipur (Rajasthan) and Raipur (Chhattisgarh).

The collected data analysed by using prepared questionnaire (Table 1) on the basis of qualitative and quantitative aspect included in AAB. Also, it is based on visualization and requirements statistical analysis input. The collected data was tabulated analysed by frequency distribution method i.e. SPSS (Computerized Software of Statistical Package for Social Science) process and from the analysed the standard format of $\mathrm{AAB}$ are suggested. This SPSS model is provided by NIC, Pune.

\section{Results and Discussion}

Farmers socio-economic levels without inclusion of weather smart agriculture are couldn't rise. In Weather-Smart agriculture ICT based Weather Forecasts and Crop Agroadvisory, are the technology. Interventions to provide services related to income security and weather advice to farmers, e.g. climate information based value added agro-advice to the farmers, income loss due to the vagaries of weather having adaptation/mitigation potential (Chhetri and Aggarwal., 2017). Hence, the study was undertaken and the existing $\mathrm{AAB}$ data revealed that, precession advice (i.e. exact seed rate, fertilizer dose, proper fertilizer application method, irrigation schedule and proper method of rationing for cattle) was not found in most of $\mathrm{AAB}$ issued by AMFU's.

\section{Weather elements based content in AAB}

The Table 2 revealed that, the weather based content of $\mathrm{AAB}$ was observed very less in percentage and also, it was found that the weather element based advice percent was lowest and it was below $30 \%$ except rainfall and cloud cover (Fig. 1). The data is revealed that the significant difference in percentage of $\mathrm{AAB}$ which was based on the different weather element were found amongst the issued $\mathrm{AAB}$ by different AMFU's and which was observed 00 to 55 percentage. While, the weather element based rainfall, maximum temperature (Tmax) minimum temperature (Tmin.) relative humidity (Rh), wind speed (WS), wind direction (WD) and cloud cover mean percentage in $\mathrm{AAB}$ issued by different AMFU's showed 24.28, 18.14, 20.71, 11.42, $20.05,26.28,21.14$ and 27.28 percent respectively, of respective centres of Parbhani, Rahuri, Dapoli, Akola, Jaipur, Sehore and Raipur AMFU. It means that, the agro advice based on accurate rainfall prediction played important role in increase the agricultural yield as well as quality. While the Tmax based agro advise in $\mathrm{AAB}$ was observed 22, 17, 14, 16, 18, 20, 20 percent of Parbhani, Rahuri, Dapoli, Akola, Jaipur, Sehore and Raipur AMFU's respectively. Whereas, Tmin based agro advice was observed in Parbhani (10\%), Rahuri (27\%), Dapoli (23\%), Akola (20\%), Jaipur (26\%), Sehore (17\%) and Raipur $(22 \%)$. 
The Table 3 revealed that the $\mathrm{Rh}$ based agro advice in AAB was observed 10, 09, 11, 13, 15, 08 and 14percent of Parbhani, Rahuri, Dapoli, Akola, Jaipur, Sehore and Raipur AMFU, respectively. Whereas, the cloud cover based agro advice in $\mathrm{AAB}$ was observed 20, 45, 55, 27, 14, 13, 17 percent in Parbhani, Rahuri, Dapoli, Akola, Jaipur, Sehore and Raipur AMFU, respectively. While, sunshine based agro advice in AAB was observed 27, 23, 21, 00, 24, 17 and 19 percent in Parbhani, Rahuri, Dapoli, Akola, Jaipur, Sehore and Raipur AMFU, respectively. Whereas the WS based agro advice in AAB was observed 27, 30, 29, 25, 31, 22and 20percent in Parbhani, Rahuri, Dapoli, Akola, Jaipur, Sehore and Raipur AMFU's respectively. The wind direction based agro advice in $\mathrm{AAB}$ was observed 20, 45, 55, 27, 14, 13, 17 percent in Parbhani, Rahuri, Dapoli, Akola, Jaipur, Sehore and Raipur AMFU, respectively.

The weather elements content based AAB (Table 3) was found highest(27.28\%) on cloud cover based and lowest (11.42\%) on Rh based; whereas, it was found decreasing order on cloud cover (27.28\%), WD (21.14\%), Tmin (20.7), BSS (20.05 \%) max. temp. $(18.14 \%)$ and $\mathrm{Rh}(11.42 \%)$.The lower percentage of agro advice based on each weather elements of $\mathrm{AAB}$ was found may be due to the ignorance of this aspect or lake of knowledge of microclimatic impact on crop at particular crop growth stage and may be due to not special mandatory provision to consider these aspects during preparation of $\mathrm{AAB}$.

\section{Agro advice based on different agricultural disciplines given in $\mathbf{A A B}$}

The important all regional agriculture crops, horticulture crops and livestock are considered during the preparation of $\mathrm{AAB}$ issued by AMFU's as per regional agricultural pattern. Analysis based on the information given in $\mathrm{AAB}$ issued was clearly indicated that there is lot of variation in content based on different disciplines of agriculture is covered. While, it was found that agro advice based on postharvest technology, processing of agricultural produce, marketing and transport was not observed in a single AAB. It is necessary; to cover these aspects in $\mathrm{AAB}$ on the basis of microclimatic condition and weather forecasting because of it will be useful to increase socio economic status of end users. It was also observed that the soil conservation practices plays vital role in reduction of evaporation losses; as well as improving the fertility and productivity of soil. Though, it is an important aspect which was ignored during preparation of AAB. It may be due to ignorance of water smart technology having adaptation potential through interventions to improve water use efficiency viz., minimisation of surface runoff and water loss from crop fields, effective control of irrigation and drainage.

\section{Alert message based Agromet Advisory Bulletin}

The separate column loss by name of alert message provided for highlighting adverse weather condition or weather calamity which causes crop in AAB (Table 3). The data revealed that, out of 7 AMFU centres only 2 AMFU (Parbhani and Sehor) incorporated alert message in AAB during the year 2011.It was found that the Parbhani centre had given weather element based alert message highest on rainfall $(81.6 \%)$ and lowest on morning relative humidity (RH-I) and evening relative humidity (RH-II) (4.8\%); cloud cover (67.2 $\%)$. Similarly, weather element based alert message given in $\mathrm{AAB}$ was highest in rainfall (14.7\%) and lowest on RH-I and RH-II (2.94 $\%)$, as well as on cloud cover $(5.88 \%)$ was observed. It is also found that the other remaining AMFU's not given alert message throughout the study period (2007-2011).It may be due to the lack of knowledge to use 
the weather services product issued by IMD in agriculture sector or may be due to complicated weather related products issued by IMD. These statements are agreement with the statement reported by Rathore et al., (2004).

\section{Existing format of $\mathrm{AAB}$}

The large variation observed in cropping pattern, local management practices and content of AAB in the different AMFU's and variation were also observed in the existing format of $\mathrm{AAB}$ which were issued by all the AMFU's. While, it was observed that the issued AAB by all AMFU's incorporated advice on different agricultural disciplines viz., agronomical crops, horticultural crops except post-harvest technology, processing of agricultural product, soil conservation practices and agricultural marketing and few of them were given advice for livestock rearing. These results are in conformity with the results of Jaybhaye et al., (2014).

The investigation of the $\mathrm{AAB}$ issued by AMFU Parbhani showed that the format of $\mathrm{AAB}$ were preciously in the form of paragraph and new existing tabular form. The running $A A B$ provides weather information in first section, separate cell for alert message was allotted in middle section to enlightening aberrant weather condition and last part of the $\mathrm{AAB}$ forecasting consisted crop information and livestock rearing management based on current, forecasted weather. The AAB issued by AMFU, Rahuri were studied and it was found that the format of bulletin was similar to Parbhani except a separate column for alert message and information about livestock production is not incorporated. However, the format of AAB issued by all other AMFU's more or less similar to Rahuri and Parbhani.

After review of AAB issued by all AMFU's found that existing $\mathrm{AAB}$ bulletin is unsuitable for the extension purpose through different media viz., print media, Radio, T.V, cellular phone, Internet and other multimedia devices etc. (i.e. I.T. tools and App's).

It is because of different gap are present between in $\mathrm{AAB}$ format, content and need of end users. The identified gaps are given as.

Tabular format of AAB was not directly usable to end users.

Academic lengthy and more non useful descriptive wordings were observed in $\mathrm{AAB}$ which was the hurdles for dissemination.

Approximation or broad ranges of recommendations given in $\mathrm{AAB}$ are not accepted by farming community.

Weather element based and crop growth stage wise agro advice was not found in most of AAB.

Precession recommendation was not observed considering real time local weather and weather forecasting.

Rainfall forecasting was not found more realistic at block level.

Existing format of $\mathrm{AAB}$ was difficult to reading and understanding to audio media i.e. AIR and local Radio stations and also it was not found suitable for SMS through cellular phone.

Hence, the number of IT companies trying to develop such types of techniques. Unfortunately, such types of completely success couldn't get to corporate sector till, however it will happen in coming days. While, on the similar line one cellular phone App for pomegranate was started by National Research Centre on Pomegranate, Solapur (MAH) (Anonyms, 2014). 
Table.1 Format data sheet for questionnaire of Agro Advisory Bulletin

\begin{tabular}{|c|c|c|c|c|c|c|c|c|c|c|c|c|c|c|c|c|c|c|c|c|c|c|c|c|}
\hline \multirow{3}{*}{\multicolumn{2}{|c|}{$\begin{array}{l}\text { Weather } \\
\text { parameters } \\
\text { covered in } \\
\text { forecasting of } \\
\text { IAAS }\end{array}$}} & \multicolumn{2}{|c|}{$\begin{array}{l}\text { Observed } \\
\text { weather } \\
\text { from } \\
\text { previous } \\
\text { week }\end{array}$} & \multicolumn{2}{|c|}{$\begin{array}{l}\text { Weather } \\
\text { forecasting } \\
\text { given in } A A B\end{array}$} & \multicolumn{2}{|c|}{$\begin{array}{c}\text { Alert } \\
\text { Message } \\
\text { given in } \\
A A B\end{array}$} & \multicolumn{2}{|c|}{$\begin{array}{c}\text { AAB is } \\
\text { Weather } \\
\text { Base }\end{array}$} & \multicolumn{15}{|c|}{ Agriculture advise covered aspects } \\
\hline & & \multirow{2}{*}{ Yes } & \multirow{2}{*}{ N } & \multirow{2}{*}{$\begin{array}{c}\text { As it } \\
\text { is }\end{array}$} & \multirow{2}{*}{$\begin{array}{l}\text { Local } \\
\text { inputs }\end{array}$} & \multirow{2}{*}{ Yes } & \multirow{2}{*}{ N } & \multirow{2}{*}{ Yes } & \multirow{2}{*}{ No } & \multicolumn{3}{|c|}{ Crops } & \multicolumn{2}{|c|}{ Live Stock } & \multicolumn{2}{|c|}{$\begin{array}{l}\text { Post } \\
\text { Harvest }\end{array}$} & \multicolumn{2}{|c|}{ Processin } & \multicolumn{2}{|c|}{$\begin{array}{c}\text { Soil } \\
\text { Conservation }\end{array}$} & \multicolumn{2}{|c|}{ Marketing } & \multicolumn{2}{|c|}{$\begin{array}{l}\text { Anyother } \\
\text { information }\end{array}$} \\
\hline & & & & & & & & & & A.C. & F.C. 0 . & C. C. Ve & Animal & Poultry & Yes & No & Yes & No & Yes & No & Yes & No & Photo Graph & Table \\
\hline \multirow{2}{*}{ Temp } & $\mathrm{TMz}$ & & & & & & & & & & & & & & & & & & & & & & & \\
\hline & TMir & & & & & & & & & & & & & & & & & & & & & & & \\
\hline \multirow{2}{*}{$\begin{array}{c}R_{i} \\
\text { Humidity }\end{array}$} & RHI & & & & & & & & & & & & & & & & & & & & & & & \\
\hline & RH2 & & & & & & & & & & & & & & & & & & & & & & & \\
\hline \multicolumn{25}{|c|}{ Rainfall } \\
\hline \multirow{2}{*}{ Wind } & W.S & & & & & & & & & & & & & & & & & & & & & & & \\
\hline & W.D & & & & & & & & & & & & & & & & & & & & & & & \\
\hline \multicolumn{25}{|c|}{ Cloud Cover } \\
\hline \multicolumn{2}{|c|}{ Sunshine } & & & & & & & & & & & & & & & & & & & & & & & \\
\hline
\end{tabular}

Table.2 Weather element content based AAB in numbers and percentage

(Data: Kharif season, 2007-2011)

\begin{tabular}{|c|c|c|c|c|c|c|c|c|c|}
\hline \multirow{2}{*}{\multicolumn{2}{|c|}{ Centers }} & \multicolumn{8}{|c|}{ AAB is weather base } \\
\hline & & \multirow[t]{2}{*}{ Rainfall } & \multicolumn{2}{|c|}{ Temp } & \multirow[t]{2}{*}{ RH } & \multirow{2}{*}{ Sunshine } & \multicolumn{2}{|c|}{ Wind } & \multirow{2}{*}{$\begin{array}{l}\text { Cloud } \\
\text { cover }\end{array}$} \\
\hline & & & Tmax & Tmin & & & W.S & W.D & \\
\hline \multirow[t]{2}{*}{ Parbhani } & No. 93 & 23 & 20 & 09 & 11 & 25 & 25 & 31 & 18 \\
\hline & $\%$ & 25 & 22 & 10 & 10 & 27 & 27 & 32 & 20 \\
\hline \multirow[t]{2}{*}{ Rahuri } & No.117 & 35 & 20 & 31 & 10 & 27 & 35 & 23 & 52 \\
\hline & $\%$ & 30 & 17 & 27 & 09 & 23 & 30 & 20 & 45 \\
\hline \multirow[t]{2}{*}{ Dapoli } & No.146 & 58 & 21 & 33 & 16 & 32 & 42 & 32 & 80 \\
\hline & $\%$ & 40 & 14 & 23 & 11 & 21 & 29 & 22 & 55 \\
\hline \multirow[t]{2}{*}{ Akola } & No. 69 & 10 & 11 & 14 & 10 & 00 & 17 & 12 & 19 \\
\hline & $\%$ & 15 & 16 & 20 & 13 & 00 & 25 & 17 & 27 \\
\hline \multirow[t]{2}{*}{ Jaipur } & No.138 & 25 & 24 & 36 & 20 & 33 & 42 & 26 & 19 \\
\hline & $\%$ & 18 & 18 & 26 & 15 & 24 & 31 & 19 & 14 \\
\hline \multirow[t]{2}{*}{ Sehor } & No. 96 & 18 & 19 & 16 & 07 & 14 & 21 & 17 & 12 \\
\hline & $\%$ & 19 & 20 & 17 & 08 & 17 & 22 & 18 & 13 \\
\hline \multirow[t]{2}{*}{ Raipur } & No. 44 & 10 & 09 & 10 & 06 & 08 & 09 & 09 & 07 \\
\hline & $\%$ & 23 & 20 & 22 & 14 & 19 & 20 & 20 & 17 \\
\hline \multirow[t]{2}{*}{ Total } & No.703 & 170 & 126 & 140 & 78 & 141 & 182 & 147 & 189 \\
\hline & $\%$ & 24.28 & 18.14 & 20.71 & 11.42 & 20.05 & 26.28 & 21.14 & 27.28 \\
\hline
\end{tabular}


Table.3 Alert message given in AAB by different AMFU's in numbers and percentage

(Data: Kharif season, 2007-2011)

\begin{tabular}{|c|c|c|c|c|c|c|c|c|c|c|}
\hline \multirow{2}{*}{\multicolumn{2}{|c|}{ Centers }} & \multicolumn{9}{|c|}{ Alert Message given in $\mathbf{A A B}$} \\
\hline & & \multirow{2}{*}{$\begin{array}{c}\text { Rainfal } \\
\text { l }\end{array}$} & \multicolumn{2}{|c|}{ Temp } & \multicolumn{2}{|c|}{ RH } & \multirow{2}{*}{$\begin{array}{c}\text { Sunshin } \\
\text { e }\end{array}$} & \multicolumn{2}{|c|}{ Wind } & \multirow{2}{*}{$\begin{array}{l}\text { Cloud } \\
\text { cover }\end{array}$} \\
\hline & & & $\underset{\mathbf{x}}{\text { Tma }}$ & $\begin{array}{c}\text { Tmi } \\
\mathbf{n}\end{array}$ & RHI & $\begin{array}{c}\text { RHI } \\
\text { I }\end{array}$ & & $\begin{array}{l}\text { W. } \\
\text { S }\end{array}$ & $\begin{array}{l}\text { W. } \\
\text { D }\end{array}$ & \\
\hline \multirow{2}{*}{$\begin{array}{c}\text { Parbhan } \\
\text { i }\end{array}$} & No. 21 & 17 & 0.0 & 0.0 & 01 & 01 & 0.0 & 0.0 & 0.0 & 14 \\
\hline & $\%$ & 81.6 & 0.0 & 0.0 & 4.8 & 4.8 & 0.0 & 0.0 & 0.0 & 67.2 \\
\hline \multirow[t]{2}{*}{ Rahuri } & No. 25 & 0.0 & 0.0 & 0.0 & 0.0 & 0.0 & 0.0 & 0.0 & 0.0 & 0.0 \\
\hline & $\%$ & 0.0 & 0.0 & 0.0 & 0.0 & 0.0 & 0.0 & 0.0 & 0.0 & 0.0 \\
\hline \multirow[t]{2}{*}{ Dapoli } & No. 29 & 0.0 & 0.0 & 0.0 & 0.0 & 0.0 & 0.0 & 0.0 & 0.0 & 0.0 \\
\hline & $\%$ & 0.0 & 0.0 & 0.0 & 0.0 & 0.0 & 0.0 & 0.0 & 0.0 & 0.0 \\
\hline \multirow[t]{2}{*}{ Akola } & No. 21 & 0.0 & 0.0 & 0.0 & 0.0 & 0.0 & 0.0 & 0.0 & 0.0 & 0.0 \\
\hline & $\%$ & 0.0 & 0.0 & 0.0 & 0.0 & 0.0 & 0.0 & 0.0 & 0.0 & 0.0 \\
\hline \multirow[t]{2}{*}{ Jaipur } & No. 32 & 0.0 & 0.0 & 0.0 & 0.0 & 0.0 & 0.0 & 0.0 & 0.0 & 0.0 \\
\hline & $\%$ & 0.0 & 0.0 & 0.0 & 0.0 & 0.0 & 0.0 & 0.0 & 0.0 & 0.0 \\
\hline \multirow[t]{2}{*}{ Sehor } & No. 34 & 05 & 0.0 & 0.0 & 01 & 01 & 0.0 & 0.0 & 0.0 & 02 \\
\hline & $\%$ & 14.7 & 0.0 & 0.0 & 2.94 & 2.94 & 0.0 & 0.0 & 0.0 & 5.88 \\
\hline \multirow[t]{2}{*}{ Raipur } & No. 20 & 0.0 & 0.0 & 0.0 & 0.0 & 0.0 & 0.0 & 0.0 & 0.0 & 0.0 \\
\hline & $\%$ & 0.0 & 0.0 & 0.0 & 0.0 & 0.0 & 0.0 & 0.0 & 0.0 & 0.0 \\
\hline \multirow[t]{2}{*}{ Total } & No.182 & 22 & 0.0 & 0.0 & 02 & 02 & 0.0 & 0.0 & 0.0 & 06 \\
\hline & $\%$ & 12.08 & 0.0 & 0.0 & 1.09 & 1.09 & 0.0 & 0.0 & 0.0 & 8.79 \\
\hline
\end{tabular}

Parbhani $\square$ Rahuri $\square$ Dapoli $\square$ Akola $\square$ Jaipur $\square$ Sehor $\square$ Raipur $\square$ Total

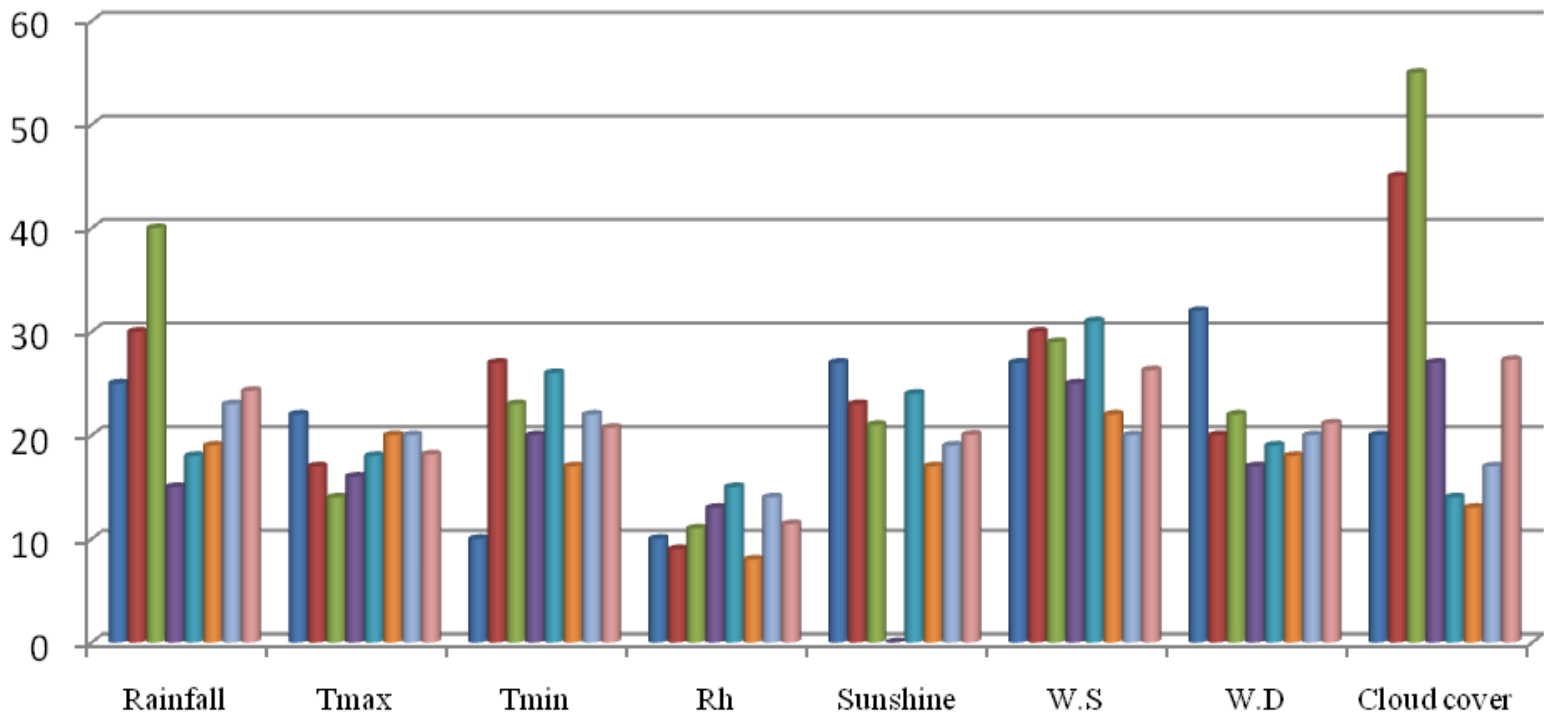

Fig.1 Weather elements content based AAB (\%) 
Fig.2 AAB pictures format suitable to multimedia and end users (Format 1)

VasantraoNaikMarathwadaKrishiVidyapeeth
Department of Agricultural Meteorology,Parbhani- 431402
Phone No. 02452-223276 Fax No. 02452-223276
Email : met_mau@ @ rediffmail.com

\begin{tabular}{|l|l|}
\hline Agro Advisory Bulletin (AAB) No. 88/20112 for Parbhani district Date : 20/01/2012 \\
\hline Previous week weather condition : & Weather condition for 20 to 24 January, 2012 \\
\hline $\begin{array}{l}\text { In the previous week weather of Parbhani district } \\
\text { was observed clear sky, } \mathrm{T}_{\max } \text { in the range } 27.5 \text { to }\end{array}$ & $\begin{array}{l}\text { In this week weather will be observe clear, wind speed } \\
\text { will be blowing by North-East to East direction with } 9 \text { to }\end{array}$ \\
$32.0{ }^{\circ} \mathrm{C}$ which is lower by $2.2{ }^{\circ} \mathrm{C}$ and higher by 2.5 & $11 \mathrm{~km} / \mathrm{hr}$. speed, maximum temperature are 27.0 to 30.0 \\
${ }^{\circ} \mathrm{C}$ than average, $\mathrm{T}_{\min }$ in the range 5.2 to $10.8{ }^{\circ} \mathrm{C}$ & ${ }^{\circ} \mathrm{C}$ and minimum temperature are 14.0 to $18.0{ }^{\circ} \mathrm{C}$ will be \\
which is lower by 1.7 to $6.9{ }^{\circ} \mathrm{C}$ than average and \\
wind speed in the range 2.2 to $4.0 \mathrm{~km} / \mathrm{hr}$. which is & $\begin{array}{l}\text { observe and relative humidity will be prevailing } 35 \text { to } 49 \\
\text { at morning and } 22 \text { to } 32 \text { at afternoon.. }\end{array}$ \\
lower by 0.2 to $1.8 \mathrm{~km} / \mathrm{hr}$ than average. &
\end{tabular}

Alert massage : In this week temperature may increase and dry and cold wind will blow.

Agromet Advisory :

\begin{tabular}{|c|c|c|c|}
\hline $\begin{array}{l}\text { Crop Growth } \\
\text { Stage }\end{array}$ & $\begin{array}{l}\text { Disease and Pest } \\
\text { Incidence }\end{array}$ & $\begin{array}{lr}\text { Agro Advise } \\
\text { Based on } \\
\text { Weather }\end{array}$ & Crop Growth Stage \\
\hline Wheat & $\begin{array}{l}\text { Flag leaf \& } \\
\text { flowering }\end{array}$ & 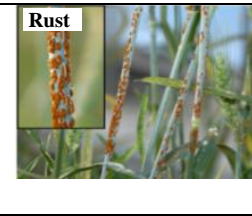 & $\begin{array}{l}\text { Now the wheat crop is in flag leaf and flowering } \\
\text { stage in this critical stage apply the irrigation to } \\
\text { wheat. Rust is observed in late sown wheat crop. For } \\
\text { controlling rust spry Hexaconazole @ } 10 \mathrm{~g} / 10 \text { lit. of } \\
\text { water }\end{array}$ \\
\hline Safflower & & & $\begin{array}{l}\text { Safflower crop should be irrigated at capsule } \\
\text { formation stage. To control aphids spray } 4.0 \mathrm{ml} \\
\text { imidaclopridor } 20 \mathrm{ml} \text { dimethoate } 30 \mathrm{EC} \text { in } 10 \text { lit. of } \\
\text { water }\end{array}$ \\
\hline & & & $\begin{array}{l}\text { Attack of Jassidesand Powdery mildew is observed } \\
\text { on mango bloom. For controlling Jassidestake spray } \\
\text { of } 4.0 \text { mlimidacloprid or thiamethoxanmixed in with } \\
10 \text { lit. of water. For Powedry mildew control spray } \\
1.0 \mathrm{ml} \text { Hexaconazolemixed with } 10 \text { lit of water. }\end{array}$ \\
\hline & & De-suckering & $\begin{array}{l}\text { Remove the new tillers of banana (De-suckering) and } \\
\text { give the soil support at the base of stem. Apply the } \\
\text { Nitrogen (Urea) dose } 2,3 \text { and } 4 \text { months after } \\
\text { plantation of Murgab banana. }\end{array}$ \\
\hline & & & $\begin{array}{l}\text { To control gummosis (Phytopthoraspp.) apply } \\
\text { Bordeaux paste on the stem of plant. For } \\
\text { Ambhebahar treatment apply soil application @ } 20 \\
\mathrm{~kg} \text { cow dung, } 1.5 \mathrm{~kg} \mathrm{~N} \text { and } 0.7 \mathrm{~kg} \mathrm{P} \mathrm{\&} \mathrm{K} \mathrm{/} \mathrm{tree} \mathrm{after} \\
\text { that give light irrigation to the crop. }\end{array}$ \\
\hline & \multicolumn{3}{|c|}{$\begin{array}{l}\text { Due to low temperture in last week attack of Foot and mouth disease is observed in Sheep and } \\
\text { Goats to control this disease apply } 10 \text { gm boric powder }+20 \mathrm{ml} \text { glycerine or give B complex } \\
\text { tablets to animals by taking the advice of Veternary Doctor. }\end{array}$} \\
\hline
\end{tabular}


Fig.3 AAB pictures format suitable to multimedia and end users (Format 2)

VasantraoNaikMarathwadaKrishiVidyapeeth
Department of Agricultural Meteorology,Parbhani -431402
Phone No. 02452-223276 Fax No. 02452-223276
Email : met_mau@ @ rediffmail.com

\begin{tabular}{|l|l|}
\hline Agro Advisory Bulletin (AAB) No. 88/20112 for Parbhani district Date: 20/01/2012 \\
\hline Previous week weather condition: & Weather condition for 20 to 24 January, 2012 \\
\hline In the previous week weather of Parbhani district & In this week weather will be observe clear, wind speed \\
was observed clear sky, $\mathrm{T}_{\text {max }}$ in the range 27.5 to & will be blowing by North-East to East direction with 9 \\
$32.0{ }^{\circ} \mathrm{C}$ which is lower by $2.2{ }^{\circ} \mathrm{C}$ and higher by & to $11 \mathrm{~km} / \mathrm{hr}$. speed, maximum temperature are 27.0 to \\
$2.5{ }^{\circ} \mathrm{C}$ than average, $\mathrm{T}_{\min }$ in the range 5.2 to 10.8 & $30.0^{\circ} \mathrm{C}$ and minimum temperatureare 14.0 to $18.0^{\circ} \mathrm{C}$ \\
${ }^{\circ} \mathrm{C}$ which is lower by 1.7 to $6.9{ }^{\circ} \mathrm{C}$ than average & will be observe and relative humidity will be \\
and wind speed in the range 2.2 to $4.0 \mathrm{~km} / \mathrm{hr}$. & prevailing 35 to 49 at morning and 22 to 32 at \\
which is lower by 0.2 to $1.8 \mathrm{~km} / \mathrm{hr}$ than average. & afternoon. \\
\hline
\end{tabular}

Alert massage: In this week temperature may increase and dry and cold wind will blow.

Agromet Advisory:

\begin{tabular}{|c|c|c|}
\hline Crop Growth Stage & $\begin{array}{l}\text { Disease and Pest } \\
\text { Incidence }\end{array}$ & Agro Advise Based on Weather \\
\hline & & $\begin{array}{l}\text { Now the wheat crop is in flag leaf and flowering } \\
\text { stage in this critical stage apply the irrigation to } \\
\text { wheat. Rust is observed in late sown wheat crop. } \\
\text { For controlling rust spry Hexaconazole @ } 10 \mathrm{~g} / \\
10 \text { lit. of water }\end{array}$ \\
\hline & & $\begin{array}{l}\text { Safflower crop should be irrigated at capsule } \\
\text { formation stage. To control aphids spray } 4.0 \mathrm{ml} \\
\text { imidaclopridor } 20 \mathrm{ml} \text { dimethoate } 30 \text { EC in } 10 \text { lit. } \\
\text { of water }\end{array}$ \\
\hline & & $\begin{array}{l}\text { Attack of Jassidesand Powdery mildew is } \\
\text { observed on mango bloom. For controlling } \\
\text { Jassidestake spray of } 4.0 \text { mlimidacloprid or } \\
\text { thiamethoxanmixed in with } 10 \text { lit. of water. For } \\
\text { Powedry mildew control spray } 1.0 \mathrm{ml} \\
\text { Hexaconazolemixed with } 10 \text { lit of water. }\end{array}$ \\
\hline & & $\begin{array}{l}\text { Remove the new tillers of banana and give the } \\
\text { soil support at the base of stem. Apply the } \\
\text { Nitrogen (Urea) dose } 2,3 \text { and } 4 \text { months after } \\
\text { plantation of Murgabag banana. }\end{array}$ \\
\hline & Gummosis & $\begin{array}{l}\text { To control gummosis (Phytopthoraspp.)apply } \\
\text { Bordeaux paste on the stem of plant. For } \\
\text { Ambhebahar treatment apply soil application @ } \\
20 \mathrm{~kg} \text { cow dung, } 1.5 \mathrm{~kg} \mathrm{~N} \text { and } 0.7 \mathrm{~kg} \mathrm{P} \mathrm{\&} \mathrm{K} \mathrm{/} \mathrm{tree} \\
\text { after that give light irrigation to the crop. }\end{array}$ \\
\hline & \multicolumn{2}{|c|}{$\begin{array}{l}\text { Due to low temperture in last week attack of foot and mouth disease is } \\
\text { observed in Sheep and Goats to control this disease apply } 10 \text { gm boric } \\
\text { powder }+20 \mathrm{ml} \text { glycerine or give B complex tablets to animals by taking the } \\
\text { advice of Veternary Doctor. }\end{array}$} \\
\hline
\end{tabular}


However, it was found that a small number of using $\mathrm{AAB}$ due to absence of vibrant $\mathrm{AAB}$ format and non-photographic information of crop, crop type, growth stage, attack of disease and pest and it's control measures, intercultural activities, use of implements and adverse weather condition mitigation practices as well as due to its nonpicturesque. To bridge such type of gap, here developed new formats of AAB (Fig. 2 and 3).

The AAB should be weather elements based with a concise and precision advice, focused on season wise agro discipline based covering different aspect viz., crop production, livestock rearing, post-harvest technology, processing, marketing and transport, agro based industries, mechanized farming, soil and water conservation practices etc.; aiming to uplifting socio economic condition of the farming community.

Separate column should be enlightened by the name of 'Alert message' to various adverse weather conditions which would causes extremely damage are lead to crop and livestock rearing. To achieve the visionary target of $\mathrm{AAB}$ and for better understanding and utilizable message transfer quicker easily to end $u$ sers, the format of $A A B$ should readable in local language and easily usable to farmers as well as end users (i.e. information technologist, media peoples and agricultural traders etc.) with attractive mode.

The existing format of $\mathrm{AAB}$ was not observed uniform of all the stations and not found easily accessible, usable format to print media. Hence, it is suggested that adopt the concise AAB in simple language and in paragraph format for print media. However, it is recommended that use the $\mathrm{AAB}$ Format 1 or Format 2 for extensive publicity and substantial adoptability of AAB through multimedia i.e. cellular phone SMS, through internet and Television etc.

\section{References}

Anonymous, 2014. ICAR-NRCP Apps (News) Daily Agroone, 25 Dec. 2014. pp: 3

Chhetri Arun Khatri and Aggarwal Pramod, K. 2017. Adapting Agriculture to Changing Climate in South Asia. World Agriculture, Article \# 1712, July 2017. www.worldagriculture.net

Henry Neufeldt, Molly Jahn, Bruce M Campbell, John R Beddington, FabriceDeClerck, Alessandro De Pinto, Jay Gulledge, Jonathan Hellin, Mario Herrero, Andy Jarvis, David LeZaks, HolgerMeinke, Todd Rosenstock, Mary Scholes, Robert Scholes, Sonja Vermeulen, Eva Wollenberg, and Robert Zougmoré. 2013. Beyond climatesmart agriculture: toward safe operating spaces for global food systems. Agriculture \& Food Security 2013, 2:12

Jaybhaye, P.R., Deore, N. H., Chattopadhyay, N. and Chandras, S. V. 2014. Studies of AAB Quality parameters to mitigate impact of climate change on Agriculture. NASA2014, international symposium, 16-18 octonber, 2014:357.

Jaybhaye, Pralhad, Shinde, P. B. and Balasubramanian, R. 2018. Impact of Agromet Advisory Bulletin (AAB) on Agro-economic Status of Farmers in Marathwada Region (Maharashtra), India. National Conference On Innovative Farming For Food And Livelihood Security In Changing Climate, 12-13 January, 2018 In Facc, Bckv, Kalyani, West Bengal. Souvenir cum abstracts FIC-2018.Pp-118.

Rao, A.S 2008. Weather based agro advisory service for food security in the Indian and region. Journal of Agro meteorology (sp. issue -2): 535- 540 .

Rathore, L.S., Singh, K.K., and Gupta, A., 2004. National Centre for Medium Range Weather Forcasting: Activities, current status and future plans. Journal of Agrometeorology 6: 258-264.

\section{How to cite this article:}

Jaybhaye, P.R., N.H. Deore and Shinde, P.B. 2018. Agromet Advisory Bulletin - A Weather Smart Agriculture Technology option for Adaptation and Mitigation of Changing Climate. Int.J.Curr.Microbiol.App.Sci. 7(02): 2644-2653. doi: https://doi.org/10.20546/ijcmas.2018.702.321 